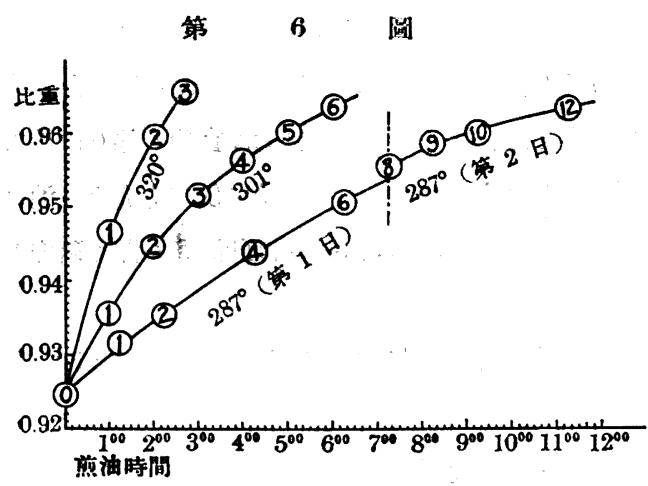

第 $\quad 7 \quad$ 圖

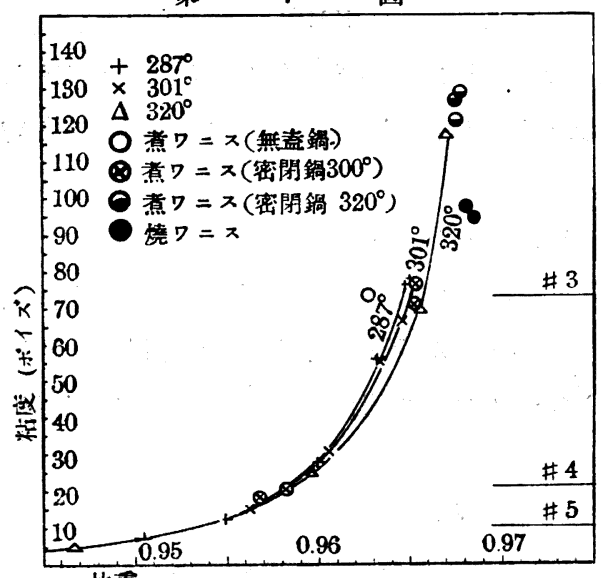

比重
第 8 圆

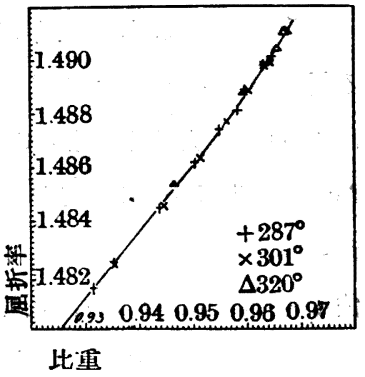

第 9 圖

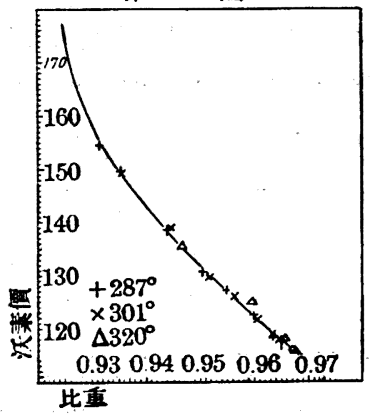

（2）煎油工程中探取した試料並に较造 ワニスの 比重, 屈折率, 粘度, 崄化價, 酸 價, 仗素價を測定し此等の 性狀を比較した。

一般に煎油溫度が高い程比重に比し粘度の小い油が得られる。整品の酸價は比較的低い。

（3） $300^{\circ} \mathrm{C}$ に於て製造したワニスは凸版及オフセラ゙ト用として無蓝鍋で製造したワニスに遜色か無い。

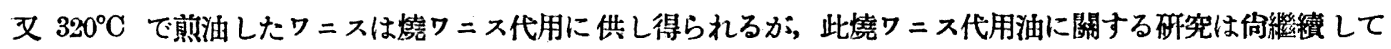
行ふ積りである。

終りに本研究を指導せられたる工學博士矢野道也氏に對し厚く感謝の意を表する。

(果京電氯株式會社)（昭和 10 年 2 月 1 日受理）

\title{
68.〔講演番號 19〕カラス中の酸化第一鐵の定量に就て
}

\section{新海 重行・高橋 樟彥}

ガラス中の酸化第一鐵の定量に關する文鶭は砝どなく，從來何人も Hillebrand 氏の著書 (The Analysis of Silicate and Carbonate rocks, 1919)に依て其測定を行つてるる樣である。然るに著者等の貫驗に体てガラス にAs を含有する場合は從來の方法に恢ては，滿足なる結果が得られないことが明かになつた。從來の方法は Cooke 氏の裝置を使用し $\mathrm{CO}_{2}$ の氣流中で $\mathrm{HF}$ に依て試料を分解し，出來るだけ $\mathrm{HF}$ を追ひ出し遊離の $\mathrm{HF}$ を不活性にする篇充分の嗍酸を添加して $\mathrm{N} / 100 \cdot \mathrm{KMnO}_{4}$ にて滴定するのである。若し $\mathrm{HF}$ の存在に於て $\mathrm{Fe} *$ 


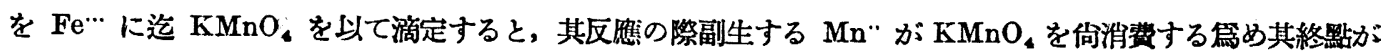
不明となる。それで Treadwell 氏 (Analytical Chemistry, Treadwell, Vol. II, 1930, 432) は此過剩の HF を除去する篇にパラフィンバっスを使用する一裝置を案出した。此考案の主な目的は䆩驗の終りに於て $120^{\circ} \mathrm{C}$ 迄 溫度を昇げて HF の大部分を除去せんとしたのであるが，Hillebrand 氏の實驗に体ても完全に迫ひ出すこと は出來なかつた。少 Barnebey 氏 (Jour. Amcr. Chem. Soc., 1915, 37, 1481) は此問題を梁く研究し貴重な業 樍を残した。

同氏に依ると $\mathrm{HF}$ に $\mathrm{H}_{3} \mathrm{BO}_{3}$ を添加すると $\mathrm{HBF}_{4}$ が生成されて其 $\mathrm{HF}$ は不活性になると云ふのである。 $4 \mathrm{HF}+\mathrm{H}_{3} \mathrm{BO}_{3}=\mathrm{HBF}_{4}+3 \mathrm{H}_{2} \mathrm{O}$

從來の方法の改訂

普通のガラスは大抵 $\mathrm{As}$ を含んでるるが之を從來の方法で $\mathrm{FeO}$ を $\mathrm{KMnO}$ 、にて滴定すると溶液が次第に 暗褐色となつて終整が不鮮明となり常に結果が過大となる。そこで As を何等かの方法で反應柔外に除去する ことが必要である。著者等は後述の方法で As を揮發せしめた。郎ちガラスが HF に依て分解されると含ま れてるる As は弗化物となるであらう。

$$
\mathrm{As}_{2} \mathrm{O}_{3}+6 \mathrm{HF}=2 \mathrm{AsF}_{3} \uparrow+3 \mathrm{H}_{2} \mathrm{O}\left(\mathrm{AsF}_{3} \text { の沸䜿は } 63^{\circ} \mathrm{C}\right)
$$

若し上記の反應系に從來の方法の如く絕えず $\mathrm{H}_{2} \mathrm{O}$ が作用すると, $\mathrm{AsF}_{3}$ は $\mathrm{H}_{2} \mathrm{O}$ に恢て分解される。郎ち 上式は逆に進行し生じた $\mathrm{As}_{2} \mathrm{O}_{3}$ が $\mathrm{H}_{2} \mathrm{O}$ に溶解しその $\mathrm{As} \cdots$ が $\mathrm{KMnO}$ 、を消費する樣に推定される。故に 著者等は Cooke 氏の裝置で湯煎を空氣浴に改良し $120 \sim 130^{\circ} \mathrm{C}$ にて操作を行ひ $\mathrm{AsF}_{3}$ として揮散せしめ滿足 なる結果を得た。

\section{試 料 の 調 製}

淸淨にした試料ガラスを迅速に粗碎し出來るだけ新鮮なる面を探取して第 1 圖に示した裝置で $\mathrm{CO}_{2}$ の氣流 中にて細粉とする。

定量方法

前述の如く調製した新鮮な試料 $0.5 \mathrm{~g}$ を白金㘫佩中に科り，第 2 回の如く轉 倒した漏斗の下に置き $\mathrm{CO}_{2}$ 發生器から $\mathrm{CO}_{2}$ を供給し空氣を完全に置換する。 次に白金坩堝中の試料を蒸溜水で濕し䄪 $10 \mathrm{cc}$ の $\mathrm{HF}$ と約 $3 \mathrm{cc}$ の $\mathrm{H}_{2} \mathrm{SO}_{4}$ と

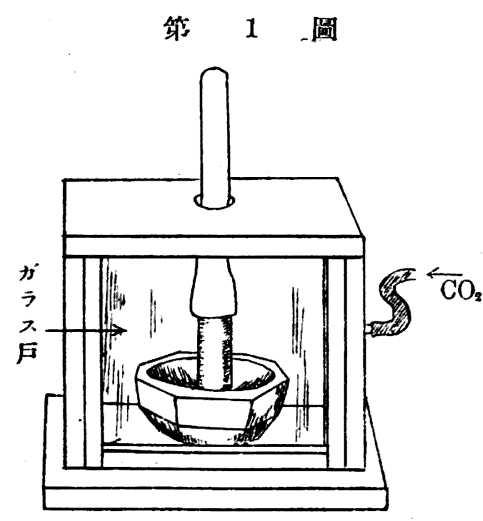

2cc の $\mathrm{HCl}$ を添加する。然る後盛 んに $\mathrm{CO}_{2}$ を供給しつ〉バーナーに點 火し空氣浴の上で $120 \sim 130^{\circ} \mathrm{C}$ に熱す る。而して $\mathrm{AsF}_{3}$ を完全に揮散せし め $\mathrm{HF}$ 及 $\mathrm{HCl}$ を成る可く追ひ出し溶 液に $\mathrm{HCl}$ の雼め着色した黄色が殆ど 脫色する迄加熱を續く。然る後消火し $\mathrm{CO}_{2}$ の氣流中にて常溫になる迄冷却 寸る。別に $\mathrm{CO}_{2}$ を以て空氣を置換し た 500ccのガラス製ビーカーに空氣遊

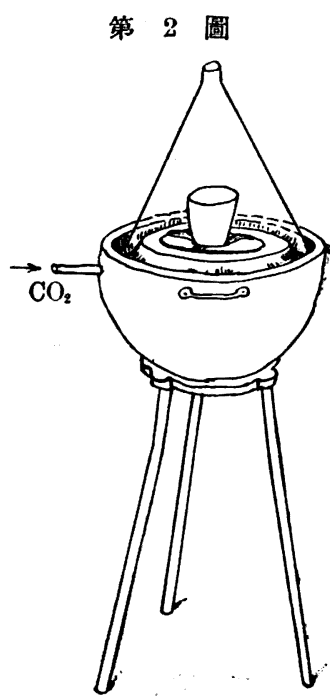

䐅の蒸溜水を約 $200 \mathrm{cc}$ と粉末の硼酸を多量加へて是に唗城の內容物を出來るだ 
け迅速に㳘入しよく洗ひ落し約 $400 \mathrm{cc}$ の容罯迄 $\mathrm{H}_{2} \mathrm{O}$ を加へ直ちに $N / 1 \mathrm{CO} \cdot \mathrm{KMnO}_{4}$ で滴定する。終點は白紙 をバっクとして紅色がかすかに着く點である。勿論 $400 \mathrm{cc} の \mathrm{H}_{2} \mathrm{O}$ に對する空試驗をなし補正する必要がある。

實驗結果

㭡 驗 第 1 .

As を含有しない同一試料に就て 從來の方法と著者等の方法との 比較實驗を行つた。其結果は次の如くで ある。

$\begin{array}{llll}\text { A } & \text { B } & \text { C } & \text { D }\end{array}$

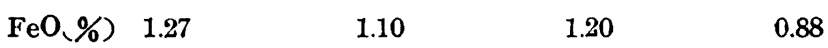
A ……Cooke 氏の裝隘を使用し從來の方法に依て湘定した。
$\mathrm{B} \cdots \cdots \cdot \mathrm{HCl}$ を加へすして空氣浴にて測定した。
$\mathrm{C} \cdots \mathrm{HCl} 2 \mathrm{cc}$ を加一て空氣浴にて定量した。
D …… と と同样にして定量したが加愁後常溫迄冷却しないで定量したるのである。

上記の結果から考察すると $\mathrm{HCl}$ を加へずに穴氣浴で操作しても差吝へないが酸化され易い傾向があるから 充分留意して實驗を行ふ必要がある。又加熱後常溫迄冷却せずして滴定することは避けねばならぬ。

實 驗 第 2.

實驗に供した試料はバっチとして $\mathrm{As}_{2} \mathrm{O}_{3} 6 \%$ を含有するるので Cooke 氏の裝置を使用して從來の方法で測 定した結果は $\mathrm{FeO} 3.62 \%$ を示せるに脚らず，此試料中の $\mathrm{Fe}$ を $\mathrm{Fe}_{2} \mathrm{O}_{3}$ として定量すると $1.98 \%$ の價を示 す。故に從來の方法に依る $\mathrm{FeO}$ の傊は明かに誤りである。

著者等の方法で定量した結果は次の如くである。

\begin{tabular}{|c|c|c|c|}
\hline 實驗番號 & 試料探取量 (g) & $\begin{array}{c}\text { 濰定に要した } \\
\text { の) cc 數 }(\mathrm{F}=0.9264)\end{array}$ & $\mathrm{FeO}(\%)$ \\
\hline 1 & 0.5000 & 1.17 & 0.16 \\
\hline 2 & $0.50 \div 0$ & 1.80 & 0.17 \\
\hline 3 & 0.5002 & 1.67 & 0.22 \\
\hline 4 & 0.5005 & 1.61 & 0.21 \\
\hline 5 & 0.5016 & 1.46 & 0.19 \\
\hline 6 & 0.5030 & 1.22 & 0.16 \\
\hline 7 & 0.5036 & 1.30 & 0.17 \\
\hline 8 & $(0.5010)$ & (0.92) & $(0.12)$ \\
\hline 9 & $(0.5005)$ & $(0.97)$ & $(0.13)$ \\
\hline
\end{tabular}

窅驗 8,9 は $\mathrm{HCl}$ を加へずに定量したもので（）內の数值がそれである。

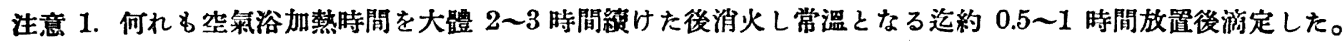
その結果を吟味すると次の如くなる。 $\mathrm{FeO}=0.18 \pm 0.03 \%$

2. 夾の試想を使用した。

$\mathrm{HCl}$ 一 保土ケ谷曹達會社製分析用合成純酫酸 $38 \%$

$\mathrm{H}_{2} \mathrm{SO}_{4}-$ Kahlbaum 彆分析用 此重 1.84

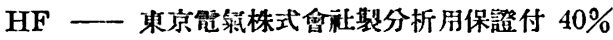

$\mathrm{H}_{3} \mathrm{BO}_{3}$ - Kahlbaum 製分析用

結論

從來のガラス中の $\mathrm{FeO}$ の定量法は $\mathrm{As}$ 含有試料に就ては適用し得ないものである。そこで著者等は Cooke 氏の装置を空氣浴として使用し $\mathrm{As}$ を $\mathrm{AsF}_{3}$ として揮散せしめ $\mathrm{FeO}$ を定量した。 
遊碓の $\mathrm{HF}$ は Bamebey 氏の主張せる如く $\mathrm{H}_{\mathbf{3}} \mathrm{BO}_{3}$ の添加に传て不活性にすることが出來た。

著者等は滴定に祭しガラスのビーカーを使用したが他の何れの器よりも非常に明膫に終點を䜋むことが出 來た。

本實驗では $\mathrm{HCl}$ を添加したが若し $\mathrm{HCl}$ 中に遊離の Cl を含む場合には筞ろ $\mathrm{HCl}$ は加へずに䆩驗を行ふ 方がよい。

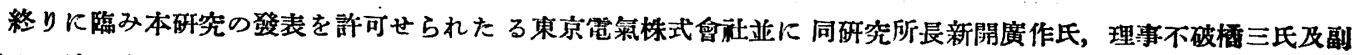
屒和田梓之介氏に對し謝意を表す。

(神奈川縣工業試驗場)（昭和 10 年 2 月 1 日受理)

\section{9.〔講演番號 2〕フラヴインヂュリン及其誘導體に就て (第 1 報)}

\section{山田 桂輔 - 野口 忠雄}

フラヴインヂュリン Flavinduline $\mathrm{C}_{26} \mathrm{H}_{17} \mathrm{~N}_{2} \mathrm{Cl}$ は 1893 年 C. Schraube (E. P. 18374,(1893); U. S. P. 543784，(1895))により合成せられたり。該染料はオルッアミド・デフェニルアミンとフェナンスラキノンとを 氷醋酸の存在に於て縮合し, 縮合生成物を直ちに稀閦酸と共に煮沸することにより比較的簡單に製造せらる。 然しなから其性質及其誘導體に關しては研究せられたるもの少なく殊に其誘導體に就ては單に分子式を列記せ るに止まれり。仍而著者等は之が性質及 $\mathrm{Br}, \mathrm{I}$ 朁を合成し其等の性質を極めんとす。

實驗 (I)

フラヴインヂュリン及其の各種ハロゲン盟の合成

(A) フラヴインヂュリンの合成

フェナンスラキノン $5 \mathrm{~g}$ 及オルソアミド・デフェニルアミン $5 \mathrm{~g}$ を $500 \mathrm{cc}$ の丸底フラスコに探りて $200 \mathrm{~g} の$ 氷醋酸を加へ湯煎上にて加熱す。時々フラスコ內容物を探りて之に稀監酸を加へ惹沸して其の液色を檢するに 最早濃度の變化を示さざる點を以て縮合の完結とす。縮合は約 2 時間にして完結す。縮合終らば之を $\mathrm{HCl}$ (38 \%) $30 \mathrm{~g}$ を加へたる水 $1.5 l$ 中に注加す。

この際液色は稍赤色を非ぶっ之を約 30 分間煮沸したる後冷却するを待ちて滤過し，濾液に留化亞鉛約 $10 \mathrm{~g}$ を加一振盪する時は暫時にして橙褐色の沈澱を析出す。之を濾過しアルコールにて再結晶を行ふ。黄赤色針狀 結晶, 收得量約 $7 \mathrm{~g}(60 \%)$ 。

此結晶をべンジールにて泩湘し次にアルコールにて再結晶を行ひ先づ Zn の定量を行ひたり。郎ち試料を白 金佣堝にて燒きて酸化物となし之を祭酸にて處理し水にて稀䆁, $\mathrm{NaOH}$ を加へて生じたる沈澱を濾過し之を白

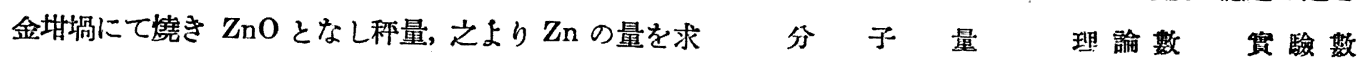
めたるに $5.77 \%$ を得たり。 $460.5 \quad 448.1$

次に朝比奈式簡易元素分析裝置に依り分析をなし， Cl は別にカリウス氏法 (Carius) に体りて定量し，次 に沸騰點法により分子量を測定したる結果は右表の如 Lo

(B) 息化水素酸篮 $\mathrm{C}_{26} \mathrm{H}_{17} \mathrm{~N}_{2} \mathrm{Br}$ の合成

$\begin{array}{ccc}\text { 元 素分 析 } & & \\ \mathrm{C}_{26} \mathrm{H}_{17} \mathrm{~N}_{2} \mathrm{Cl} \cdot \mathrm{x} / 2 \mathrm{ZnCl}_{2} & \text { 理 諭數\% } & \text { 實 驗 數\% } \\ \mathrm{C} & 67.75 & 66.20 \\ \mathrm{H} & 3.69 & 4.60 \\ \mathrm{~N} & 6.08 & 6.70 \\ \mathrm{Cl} & 15.42 & 15.77 \\ \mathrm{Zn} & 7.05 & 5.77\end{array}$

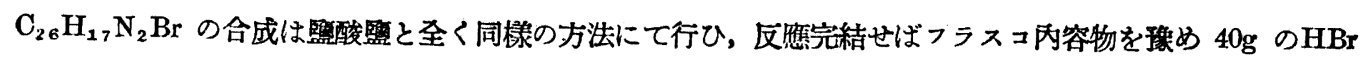

